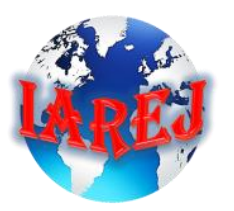

Available online at www.dergipark.gov.tr

INTERNATIONAL ADVANCED RESEARCHES

and

ENGINEERING JOURNAL

Research Article

\title{
Experimental investigation of the effect of compression pressure on mechanical properties in glass fiber reinforced organic material-based brake pads production
}

\author{
Sait Aras ${ }^{a} *$ (D) and Necmettin Tarakçı̆ğlu ${ }^{b}$ \\ ${ }^{a}$ Selçuklu Vocational and Technical Anatolian High School, Department of Motor Vehicle Technology, Konya, 42070, Turkey \\ ${ }^{b}$ Selçuk University, Faculty of Technology, Department of Metallurgy and Materials Engineering, Konya, 42030, Turkey
}

\begin{tabular}{|c|c|}
\hline ARTICLE INFO & ABSTRACT \\
\hline $\begin{array}{l}\text { Article history: } \\
\text { Received } 30 \text { July } 2018 \\
\text { Revised } 22 \text { December } 2018 \\
\text { Accepted } 18 \text { April } 2019 \\
\text { Keywords: } \\
\text { Brake pads } \\
\text { Coefficient of friction } \\
\text { Compression press } \\
\text { Hardness } \\
\text { Juniperus drupacea } \\
\text { Wear ratio }\end{array}$ & $\begin{array}{l}\text { In this study, samples which can be used as brake pads are prepared. A mixture of } 50 \% \text { barite by } \\
\text { mass, } 20 \% \text { glass fiber, } 25 \% \text { phenolic resin and } 5 \% \text { coke powder was prepared, and } 6 \text { samples were } \\
\text { prepared by adding juniperus drupacea nut powder (JDNP) at } 10 \%, 25 \% \text { and } 40 \% \text {. The samples } \\
\text { were produced in } 3 \text { different mixing times, } 2 \text { different compaction times, } 3 \text { different compaction } \\
\text { temperatures and } 3 \text { different compression pressures. The effect of the compression pressure on the } \\
\text { wear rate, hardness, density and cold friction coefficient was investigated. The wear rate ranges } \\
\text { from } 0.093 .10^{-7}-4.235 .10^{-7} \mathrm{~cm}^{3} . \mathrm{N}^{-1} \cdot \mathrm{m}^{-1} \text {. The coefficient of cold friction ranges from } 0.30 \text { to } 0.48 \text {. } \\
\text { The density is between } 1.82-2.17 \mathrm{~g} / \mathrm{cm}^{3} \text {. The hardness values are from } 85 \text { to } 117 \text { according to the } \\
\text { Rockwell R scale. Wear rate and cold friction coefficient values are in accordance with TS } 555 \\
\text { standard. It has been determined that the compressive pressure is most affected by the hardness } \\
\text { and friction coefficient. Generally, rise of pressure reduces hardness and friction coefficient. The } \\
\text { effect of density on JDNP ratio is opposite. }\end{array}$ \\
\hline
\end{tabular}

(C) 2019, Advanced Researches and Engineering Journal (IAREJ) and the Author(s).

\section{Introduction}

People have to complete their needs by either moving or carrying in order to make their lives earlier to get food, beverages, fuel or energy. They use different means of transportation for these needs.

The oldest known wheel remains dates from 3000 to $2500 \mathrm{BC}$ [1]. Although the invention of the wheel goes back 5000 years, the history of motor vehicles is about 130 years.

People acquire the necessary energy from the internal combustion engines that burn different fuels when transporting themselves and the materials they need. This movement of the motor is transmitted by the powertrain to the wheels by adjusting the speed, direction and torque.

The vehicles produce kinetic energy while moving. The brake system turns this energy into heat energy.

The use of frictional forces in the moving bodies to produce a deceleration mechanism and to form between the two sliding bodies in contact with each other has historically been up to the beginning of the first tests of mankind [2].

The performance of the system depends on the friction between the pads that presses against the rotating disk (or drum).

The numerical value of friction is practically always present even if it is too small to be taken into account [3]. Friction should be within certain values between the respective surfaces. A typical example is the fact that the vehicle cannot stop at the desired distance and time due to low friction in the vehicle brakes or that the brakes of the vehicle are blocked due to excessive friction [4].

The most important factor of braking performance is the stopping distance after braking. This is possible by maximum deceleration acceleration. High braking performance is related with high quality braking pads which constitutes a significant portion of the friction surfaces [5].

\footnotetext{
* Corresponding author. Tel.: +90 53271152 27, Fax: +90 3322412179

E-mail addresses: saitaras@gmail.com (S.Aras),ntarakcioglu@selcuk.edu.tr (N.Tarakçığlu)

ORCID: 0000-0003-2618-535X (S. Aras), 0000-0003-0742-6699 (N. Tarakçıŏlu)

DOI: $10.35860 /$ iarej.449089
} 
Abrasion is an inevitable consequence of friction [4]. Wear; temperature, lubrication, working conditions, environment, surface roughness, material pair etc. elements are connected to a system [6]. The contact area of the two friction surfaces is called the mechanical interaction area. This area has a significant effect on wear [7].

Braking systems consist mainly of two rubbing elements fig.1. These are called lining and disc/drum. As we don't have a specific formula for the materials used in these pads, development studies for better pads are still going on [8].

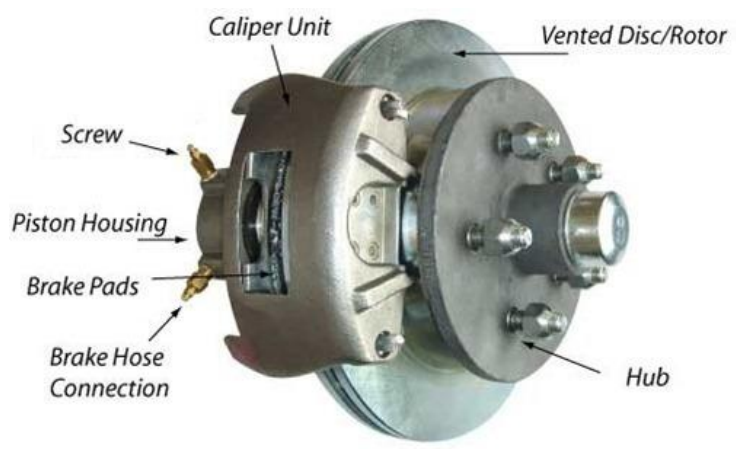

Figure 1. Disc brake unit [9]

The affecting factors to braking pads are components and producing parameters as it surged in studies of braking.

While producing brake pads hundreds of different materials in different rates are tried. Among the parameters affecting the produced brake pads are distinguishing as mixing type, duration of mixing, pressing temperature, pressing pressure, pressing time and sintering time.

Applied pressure value changes from $5 \mathrm{MPa}$ to 4000 $\mathrm{MPa}$ in literature. If the pressure is to be applied cold, the pressure value is high, and if it is hot, it is lower.

Some of the applying pressing pressure, pressure heat, sort are given in the table 1 bellow.

Table 1. Compression pressures and temperatures in the literature

\begin{tabular}{ccr}
\hline Pressing pressure & Pressing temperature & \\
$15 \mathrm{MPa}$ & $153^{\circ} \mathrm{C}$ & {$[10]$} \\
$15 \mathrm{MPa}$ & $150^{\circ} \mathrm{C}$ & {$[11]$} \\
$8 \mathrm{MPa}$ & $150^{\circ} \mathrm{C}$ & {$[12]$} \\
$15 \mathrm{MPa}$ & $150^{\circ} \mathrm{C}$ & {$[13]$} \\
$500 \mathrm{MPa}$ & cold pressing & {$[14]$} \\
$400 \mathrm{MPa}$ & room temperature & {$[15]$} \\
$1000-400-4000-600 \mathrm{MPa}$ & $150-170^{\circ} \mathrm{C}$ & {$[16]$} \\
$5-7,5-10-12,5 \mathrm{MPa}$ & $125^{\circ} \mathrm{C}$ & {$[2]$} \\
$150-250 \mathrm{bar}$ & $150-180^{\circ} \mathrm{C}$ & {$[17]$} \\
$25 \mathrm{Mpa}$ & $150^{\circ} \mathrm{C}$ & {$[18]$} \\
$10,15,20 \mathrm{Mpa}$ & $180^{\circ} \mathrm{C}$ & {$[19]$} \\
$100 \mathrm{Mpa}$ & $160^{\circ} \mathrm{C}$ & {$[20]$} \\
$100 \mathrm{bar}$ & $150^{\circ} \mathrm{C}$ & {$[8]$} \\
$50-100-200-300 \mathrm{Mpa}$ & $150^{\circ} \mathrm{C}$ & {$[21]$} \\
\hline
\end{tabular}

In this study the braking pad consists of barite, phenolic resin, glass fiber, coal and juniperus drupacea nut powder (JDNP). The effect of the formed pressures on the hardness, friction coefficient, density and wear rate of different pressing pressures were investigated by changing the pressing pressures to 100,150 and $200 \mathrm{MPa}$, which are considered to affect the properties of the starting material.

\section{Material and Method}

While preparing samples used in research $50 \%$ barite, $20 \%$ glass fiber, $25 \%$ phenolic resin, $5 \%$ coal powder are used and to this mixture, a mass of $10 \%, 25 \%, 40 \%$ rate JDNP is added.

\subsection{The sample inclusion and specifications}

The barite used in this study is $5 \mu \mathrm{m}$ volume and obtained from "Barit Maden Türk AŞ." company. The technical specifications of barite are given in the Table 2 .

Table 2. Technical specifications of barite [22]

\begin{tabular}{|l|c|c|}
\hline $\mathrm{BaSO}_{4}$ & $\%$ & $91-93$ \\
\hline Density & $\mathrm{g} / \mathrm{cm}^{3}$ & $4,25(\mathrm{~min})$ \\
\hline Hardness & Moh's & $3-3,5$ \\
\hline Humidity / Factory exit & $\%$ & $0,1(\max )$ \\
\hline Oil absorbing value & $\mathrm{mL} / 100 \mathrm{~g}$ & $15-16$ \\
\hline Acidity value $(\mathrm{pH})$ & $\%$ & $6-8$ \\
\hline
\end{tabular}

The resin suitable for CK 82790 type disc and drum lining is supplied from Çukurova Kimya Endüstrisi AŞ.

The coke was turned into powder in Selçuk University Mining Engineering Laboratory.

$3 \mathrm{~mm}$ broken glass fiber bunch (PH2) suitable for the production of phenolic linings is used which was produced by "Cam Elyaf Sanayi AŞ. Gebze/Kocaeli". The product specifications of glass fiber are given in the table 3 .

Table 3. Product specifications of glass fiber [23]

\begin{tabular}{|l|l|}
\hline Glass Type & E \\
\hline Filament Diameter $(\mu)$ & Nom. 13 \\
\hline Moisture Content $(\%)$ & max. 0,07 \\
\hline Sizing Type & Silane \\
\hline Sizing Content $(\%)$ & $0,90 \pm 0,15$ \\
\hline Flowability & Very good \\
\hline Resin Compatibility & Phenolic \\
\hline Chopped Length $(\mathrm{mm})$ & 3 \\
\hline
\end{tabular}

In Figure 2(a) juniperus drupacea nuts (JDN) are collected from nature and dried in the sun light. They were washed to get rid of soil and sand and dried again. The photos of broken nuts are in Figure 2(b). The JDN, which was subjected to dehumidification after being broken, was turned into powder Figure 2(c) at Selçuk University Mining Engineering Laboratory. 


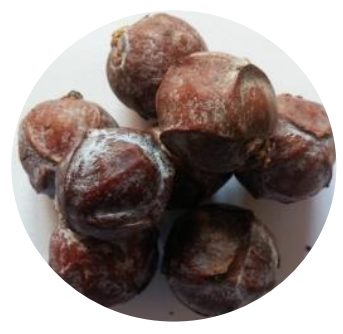

(a)

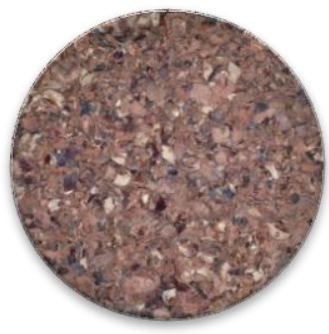

(b)

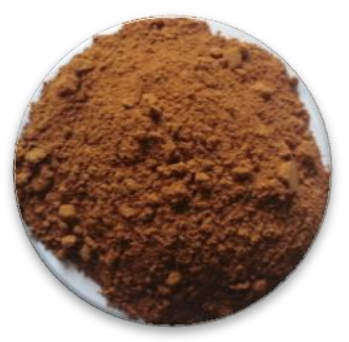

(c)

Figure 2. Pictures of juniperus drupacea nuts (JDN) [24]

All the powders were sieved in $\leq 1 \mathrm{~mm}$. In order to ensure homogeneous distribution of the materials used in the sample production, all of the materials forming the samples were mixed at the mixing times specified in table 4 in the blade mixer.

The contents and parameters used in studies are given in the table 4 below.

Table 4. Sample contents and production parameters

\begin{tabular}{|c|c|c|c|c|c|}
\hline \multirow{2}{*}{$\begin{array}{c}\text { Sample } \\
\text { No }\end{array}$} & \multicolumn{3}{|c|}{ Pressing } & \multirow{2}{*}{$\begin{array}{c}\text { Mixing } \\
\text { time } \\
(\mathrm{min})\end{array}$} & \multirow{2}{*}{$\begin{array}{c}\text { JDNP } \\
(\%)\end{array}$} \\
\hline & $\begin{array}{c}\text { Duration } \\
(\mathrm{min})\end{array}$ & $\begin{array}{c}\text { Pressure } \\
\text { (MPa) }\end{array}$ & $\begin{array}{r}\text { Temp. } \\
\left({ }^{\circ} \mathrm{C}\right)\end{array}$ & & \\
\hline 1 & 10 & 100 & 140 & 10 & 10 \\
\hline 2 & 10 & 150 & 160 & 15 & 25 \\
\hline 3 & 10 & 200 & 180 & 20 & 40 \\
\hline 4 & 15 & 200 & 180 & 10 & 25 \\
\hline 5 & 15 & 100 & 140 & 15 & 40 \\
\hline 6 & 15 & 150 & 160 & 20 & 10 \\
\hline
\end{tabular}

\subsection{The experiments}

In order to get the friction coefficient and wear rate of the produced samples, the wear test was carried out with a Turkyus brand abrading device (Figure 3).

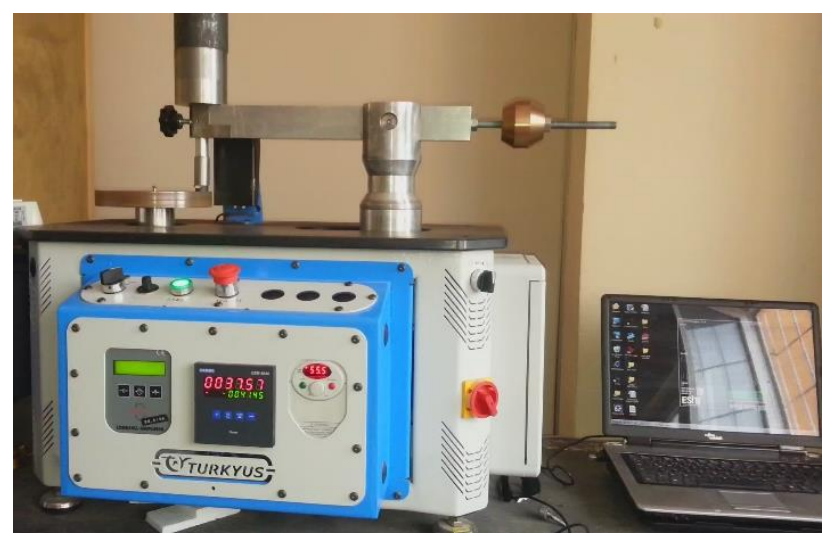

Figure 3. Wear tester
Wear rate tests were carried out using a pin-on-disc type tribo-test machine. The pin-on-disc test apparatus with disc made of grey cast iron of hardness value $195 \mathrm{HB}(62.5 \mathrm{~kg} . f$, $5 \mathrm{~mm}$ ball) and $180 \mathrm{~mm}$ track diameter was used to investigate the dry sliding wear rate of the brake pad specimens in accordance with ASTM:D792 standard [25].

Load cell located on the device detects the forces axially generated under constant load after the rotation movement starts and transfers the data to the computer program. The wear rate is measured according to the mass loss principle by measuring the masses before and after the wear test; was calculated using equation (1).

$$
W_{a}=\frac{\Delta G}{\rho \cdot M \cdot S}\left(m m^{3} \cdot N^{-1} \cdot m^{-1}\right)
$$

The hardnesses of the samples were measured on the rockwell R scale (1/2" ball 10kgf preload, 60kgf total load) in the Digirock ${ }^{\circledR}$ brand hardness tester produced by Bulut Makine Sanayi ve Ticaret Ltd.Şti (Figure 4).

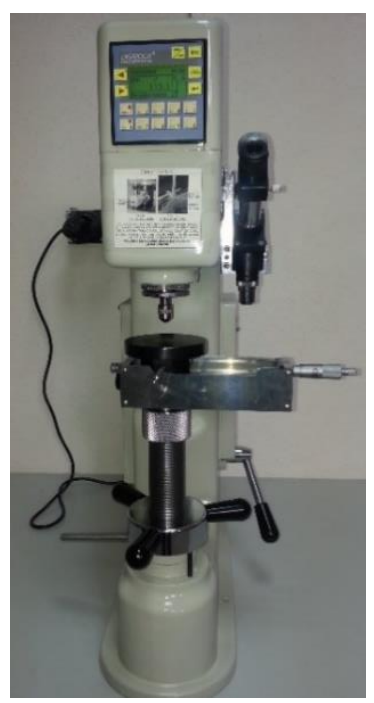

Figure 4. Hardness Tester

For the calculation of sample densities, sample masses were weighed with a $1 \mathrm{mg}$ precision scales, sample diameters and heights were measured with digital calipers with a sensitivity of $0.01 \mathrm{~mm}$ in three different axes and calculated with equation (2).

$$
\rho=\frac{m}{\frac{\pi \cdot D^{2} \cdot h}{4}}\left(\mathrm{~g} \cdot \mathrm{cm}^{-3}\right)
$$

In order to calculate the friction coefficient, during the wear test, the load cell data stored in the wear device were recorded on the computer momentarily. The mean cold friction coefficient was calculated by taking the average of the recorded data during the wear test.

\subsection{The results of the experiments}

It was found that the most wear on the pin-on-disk test to determine the wear rate was at the sample 5. It came out that it was produced 100MPa pressure, the lowest one. Another 
factor is the reduced sample density, which is high for the proportion of JDNP participating in the sample. Thus, the decrease in density caused the wear rate to increase.

The least wear rate is in the number 2, where the pressing pressure is at the mid-level of $150 \mathrm{MPa}$ and the minimum rate of JDNP.

The wear rate values of the samples were given in the Figure 5.

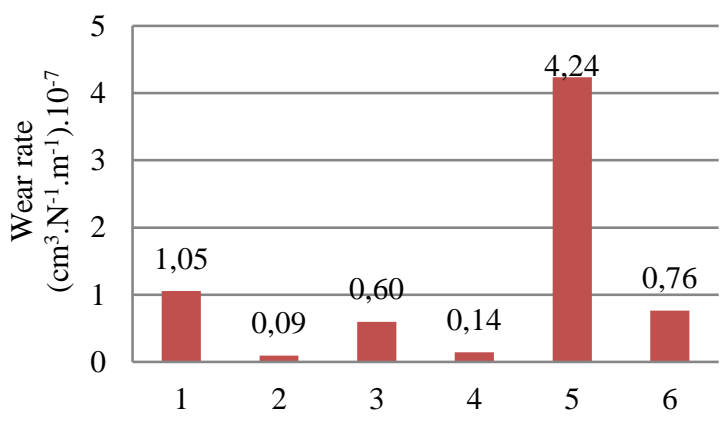

Figure 5. Wear rate graph

When the wear rate graph in fig. 5 and the table 3 are examined together, it is seen that the higher the pressing pressure, the lower the wear rate.

While the wear rate is calculated, the density is also in the denominator. The wear rate is expected to decrease while the density goes up in experiments done in the same conditions. But the density itself isn't the main factor for the wear rate. When we have a look at the graphs in 3 and 4 together, the density of sample 5 is seen low whereas the wear rate is the highest. When the properties of the sample 5, which has the highest wear rate, are examined from table 4, it will be seen that the pressing pressure and pressing temperature is the lowest and the rate of JDNP is the highest. When the wear rates and production parameters of samples 3 and 5 with JDNP at the same rate are examined together, the wear rate of sample 3 is seen to be lower. In order to reduce the wear rate in the use of high-rate JDNP, increasing the pressing pressure and pressing temperature can be a solution.

This condition can be explained by the hardness graph of fig. 7 and the graph of the mean cold friction coefficient in fig. 8, which show that the coefficient of friction of the sample 5 is the highest and that the hardness is relatively small.

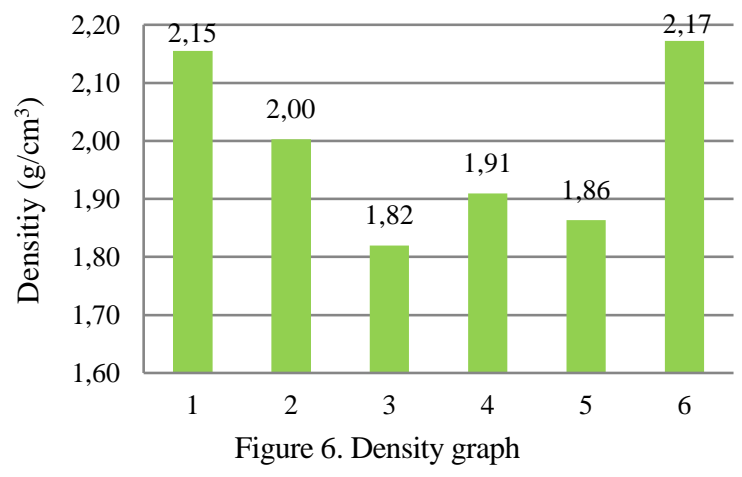

High density values were found in samples with low JDNP ratio and low density values were in samples using high JDNP. In other words, the JDNP ratio is increased, the sample density is decreasing.

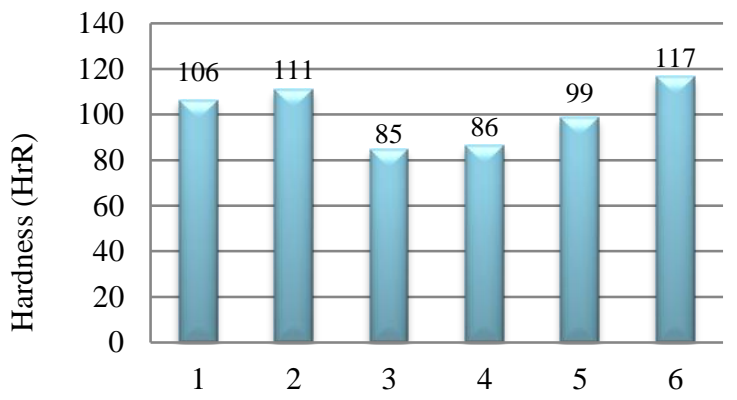

Figure 7. Hardness graph

The pressing pressure alone has not been associated with the hardness value. However, when the samples produced at the same pressing pressure are compared, the hardness of samples with a higher JDNP ratio is lower, while the hardness of samples with a lower JDNP ratio is higher.

As the pressing pressure increases, it is generally seen that the friction coefficient decreases. Figure 8 shows the average cold friction coefficient [26] values of the samples during the wear test.

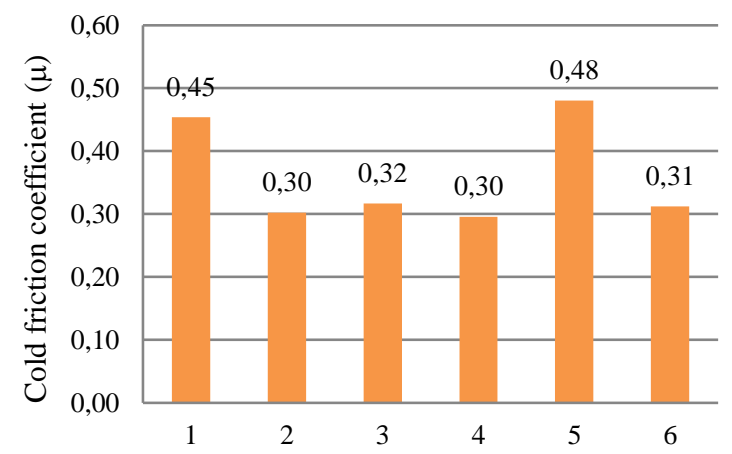

Figure 8. Average cold friction coefficient graph

\section{Conclusions}

The wear rate values change between $0.093 .10^{-7}$ 4.235.10 $10^{-7} \mathrm{~cm}^{3} \cdot \mathrm{N}^{-1} \cdot \mathrm{m}^{-1}$. These values are lower than the minimum wear rate specified in TS 555 .

The friction coefficient ranges from 0.30 to 0.48 . When compared with TS555 values, these values were found to be the E class of 4 samples, the $G$ class friction coefficient of 2 samples, and all the samples were found to conform to the standard [27].

The density changes between $1.82-2.17 \mathrm{~g} / \mathrm{cm}^{3}$. The direct effect of pressure to density couldn't be noticed. Density and JDNP rate have reverse effect.

Hardness values range from 85-117 according to the Rockwell R scale.

The hardness values of the samples (2 and 6) produced were higher than the results of the other samples while the pressing pressure was at the medium level (150 MPa). Also, when the pressing pressure is increased to the highest $(200$ $\mathrm{MPa}$ ), the produced specimens ( 3 and 4 ) are found to fall to the lowest level.

The pressing pressure mostly effected the hardness and 
friction coefficient. Generally, the excess of pressing force reduces the hardness and friction coefficient.

The wear rate of the samples with low pressing pressure is higher than the wear rate of other samples.

\section{Acknowledgment}

This work was supported by Selçuk University Scientific Research Projects Coordination Unit within the scope of $\mathrm{PhD}$ thesis Project 16201089.

We would like to thank Selçuk University Scientific Research Projects Coordination Unit for their support.

\section{Nomenclature}

$\begin{array}{ll}\mathrm{Wa} & : \text { wear rate }\left(\mathrm{mm}^{3} \cdot \mathrm{N}^{-1} \cdot \mathrm{m}^{-1}\right) \\ \Delta \mathrm{G} & : \text { mass loss }(\mathrm{mg}) \\ \mathrm{S} & \text { : sliding distance }(\mathrm{m}) \\ \mathrm{M} & : \text { loading weight }(\mathrm{N}) \\ \rho & : \text { sample density }\left(\mathrm{g} / \mathrm{cm}^{3}\right) \\ \mathrm{h} & : \text { sample height }(\mathrm{cm}) \\ \mathrm{m} & : \text { sample mass }(\mathrm{g}) \\ \mathrm{D} & : \text { sample diameter }(\mathrm{cm}) \\ \text { JDN } & : \text { juniperus drupacea nut } \\ \text { JDNP } & : \text { juniperus drupacea nut powder }\end{array}$

\section{References}

1. Ulkemiz.com [2018 October 21]; Avalilable from http://www.ulkemiz.com/tekerlegin-icadi-ve-tarihselgelisimi

2. Ertan, R. Fren Balata Malzemelerinin Optimizasyonu ve Üretim Parametrelerinin Analizi, Uludağ Üniversitesi, Fen Bilimleri Enstitüsü, Doktora Tezi, Bursa, 2008.

3. Karaoğlu, Y., Bir Aşınma Test Cihazının Tasarımı ve Imalat,, Sakarya Üniversitesi, Fen Bilimleri Enstitüsü, Yüksek Lisans Tezi, Sakarya, 2006.

4. Sugözü, İ., Bor Katkllı Asbestsiz Otomotiv Fren Balatası Üretimi ve Frenleme Karakteristiğinin İncelenmesi, Firat Üniversitesi, Fen Bilimleri Enstitüsü, Doktora Tezi, Elazığ, 2009.

5. Domaç, G.S., Disk Frenlerin Tasarım ve Tribolojik Açıdan Incelenmesi, Yıldız Teknik Üniversitesi, Fen Bilimleri Enstitüsü, Doktora Tezi, İstanbul, 2006.

6. Kuş, H., Bronz Esaslı Seramik Takviyeli Fren Balatalarının Performansinin Geliştirilmesi, Gazi Üniversitesi, Fen Bilimleri Enstitüsü, Doktora Tezi, Ankara, 2014.

7. Boz, M., Seramik Takviyeli Bronz Esaslı Toz Metal Fren Balata Üretimi ve Sürtünme-Aşınma Özelliklerinin Araştırılması, Gazi Üniversitesi, Fen Bilimleri Enstitüsü, Doktora Tezi, Ankara, 2003.

8. Üstün, N.S., Otomotiv Endüstrisi Iç̧in Bir Disk Fren Balatasi Üretimi ve Performansinin İncelenmesi, Süleyman Demirel Üniversitesi, Fen Bilimleri Enstitüsü, Yüksek Lisans Tezi, Isparta, 2011.

9. Makinemuh.com [2018 July 18]; Avalilable from: http://mesnet.makinemuh.com/otomobillerde-mekanikfren-sistemi-nasil-calisir

10. Kumar, M., B.K. Satapathy, A. Patnaik, D.K. Kolluri and B.S. Tomar, Hybrid composite friction materials reinforced with combination of potassium titanate whiskers and aramid fibre: Assessment of fade and recovery performance, Tribology International, 2011, 44(4): p. 359-367.
11. Öztürk, B., F. Arslan and S. Öztürk, Hot wear properties of ceramic and basalt fiber reinforced hybrid friction materials, Tribology International, 2007, 40: p. 37 - 48.

12. Kumar, M., X. Boidin, Y. Desplanques and J. Bijwe, Influence of various metallic fillers in friction materials on hot-spot appearance during stop braking, Wear, 2011, 270(5-6), p. 371-381.

13. Satapathy, B.K. and J. Bijwe, Performance of friction materials based on variation in nature of organic fibres Part I. Fade and recovery behaviour, Wear, 2004, 257(5-6), p. 573-584.

14. Albayrak, B., Bronz Balatalarn Üretimi ve Performans Testleri, Sakarya Üniversitesi, Fen Bilimleri Enstitüsü, Yüksek Lisans Tezi, Sakarya, 2009.

15. Stadler, Z., K. Krnel and T. Kosmac, Friction and wear of sintered metallic brake linings on a C/C-SiC composite brake disc, Wear, 2008, 265(3-4), p. 278-285.

16. Dante, R.C., F. Vannucci, P. Durando, E. Galetto and C.K. Kajdas, Relationship between wear of friction materials and dissipated power density, Tribology International, 2009, 42(6), p. 958-963.

17. Akagündüz, E., Kompozit sürtünmeli fren balatalarinda yerli uçucu kül katkisinin raylı taşıt balata özelliklerine etkisininin incelenmesi ve kullanilabilirliğinin saptanması, Yıldız Teknik Üniversitesi, Fen Bilimleri Enstitüsü, Doktora Tezi, İstanbul, 2014.

18. Adıgüzel, A.A., Katı Yağlayıcı ve Aşındırıcı Bileşenlerinin Fenolik Reçine Esasl Fren Balatalarının Mekanik ve Tribolojik Özelliklerine Etkileri, Karadeniz Teknik Üniversitesi, Fen Bilimleri Enstitüsü, Yüksek Lisans Tezi, Trabzon, 2015.

19. Sugözü, İ., İ. Yavuz and İ. Mutlu, Polimerik Kompozit Sürtünme Malzemelerinde Üretim Basincinın Performansa Etkisinin Araştırılması, in IATS'09, Karabük, p. 1140-1143.

20. Demirhan, Y. Z., Yüksek Performansl Para-Aramid Elyaf Takviyeli Fren Balatalarının Mekanik Özelliklerinin Araştırılması, Selçuk Üniversitesi, Fen Bilimleri Enstitüsü, Yüksek Lisans Tezi, Konya, 2017.

21. Unaldi, M. and R. Kus, Effect of Pressing Pressure on Density and Hardness of Powder Miscanthus Reinforced Brake Pads, Applied Mechanics and Materials, 2014, 680, p. 237-240.

22. Baritmaden [2018 July 18 ]; Avalilable from: http://www.baritmaden.com/endustriyelmineraller/belgeler /TDS.11072017.pdf

23. Sisecam [2018 July 18 ]; Avalilable from: http://www.sisecamkimyasallar.com/sites/catalogs/en/Doc uments/buss-seg/Cam-Elyaf/kirpma/sisecam-PH2.pdf

24. Aras S. and N. Tarakçıŏlu, The Usage of Some Organic Materials in Brake Pad Composition and Researching the Results, in ICNASE'16: Kilis. p.1099-1105

25. Unaldi M. and R. Kus, The effect of the brake pad components to the some physical properties of the ecological brake pad samples, IOP Conference Series: Materials Science and Engineering, 2017, 191(1), p. 012032

26. TS 9076, Karayolu Tașitlar Fren Sistemleri Fren Balataları Malzeme Sürtünme Özelliklerinin Küçük Deney Parçaları İle Değerlendirilmesi, Ankara, 1991.

27. TS 555, Karayolu Taşıtları Fren Sistemleri Balatalar Sürtünmeli Frenler Iç̧in, Ankara, 1992. 